\title{
Communication \\ Successful Disinfection of a New Healthcare Facility Contaminated with Pseudomonas aeruginosa
}

\author{
Alain Ficheux ${ }^{1}{ }^{\circledR}$, Jérémy Réthoret ${ }^{1}$, Jonas Laget ${ }^{1}$, Cristel Baux ${ }^{2}$, Nathalie Gayrard ${ }^{1} \oplus$, Flore Duranton ${ }^{1}{ }^{\circledR}$, \\ Fernando Vetromile ${ }^{2}$, Ilan Szwarc ${ }^{2}$, Chantal Cazevieille ${ }^{3}$, Marie-Françoise Servel ${ }^{2}$ and Àngel Argilés $1,2, *(1)$ \\ 1 RD-Néphrologie, 2 rue de Mûriers, 34090 Montpellier, France; ficheux@rd-n.org (A.F.); \\ jrethoret@gmail.com (J.R.); jonaslaget@hotmail.com (J.L.); nathalie.gayrard@umontpellier.fr (N.G.); \\ duranton@rd-n.org (F.D.) \\ 2 Centre de Dialyse de Sète, Néphrologie Dialyse St Guilhem, Bd Camille Blanc, 34204 Sète, France; \\ cbaux@ndsg.fr (C.B.); fvetromile@ndsg.fr (F.V.); iszwarc@ndsg.fr (I.S.); servelmf@ndsg.fr (M.-F.S.) \\ 3 Institut des Neurosciences, CoMET MRI Facilities, Université de Montpellier, 80 Av. Augustin Fliche, \\ 34000 Montpellier, France; chantal.cazevieille@inserm.fr \\ * Correspondence: argiles@rd-n.org
}

check for updates

Citation: Ficheux, A.; Réthoret, J.;

Laget, J.; Baux, C.; Gayrard, N.;

Duranton, F.; Vetromile, F.; Szwarc, I.;

Cazevieille, C.; Servel, M.-F.; et al.

Successful Disinfection of a New

Healthcare Facility Contaminated

with Pseudomonas aeruginosa. Hygiene

2022, 2, 1-13. https://doi.org/

10.3390/hygiene2010001

Academic Editor: Günter Kampf

Received: 18 November 2021

Accepted: 20 December 2021

Published: 30 December 2021

Publisher's Note: MDPI stays neutral with regard to jurisdictional claims in published maps and institutional affiliations.

Copyright: () 2021 by the authors. Licensee MDPI, Basel, Switzerland. This article is an open access article distributed under the terms and conditions of the Creative Commons Attribution (CC BY) license (https:// creativecommons.org/licenses/by/ $4.0 /)$.

\begin{abstract}
Contamination of water use points in health establishments is a frequent and concerning problem. Maintenance and disinfection of water systems can be inefficient. Sterilizing filters are commonly used at selected taps. We report diagnostic and corrective approaches that have succeeded in making a contaminated health facility sustainably compatible with its activity without restriction in taps use. The zones contaminated with pseudomonas as well as those, along the water networks, at risk of biofilm development were identified. Corrective measures on the network and various types of decontamination were carried out. At the end of this work, the bacterial load in the water significantly decreased and 219 out of 223 controls were negative for P. aeruginosa over 3 years of follow-up. Four positive results were linked to three taps not used for care which were satisfactorily treated locally. Errors at the design and setup phases of health facilities may result in resistant bacterial contamination. P. aeruginosa contamination of newly built healthcare facilities is an underreported problem. Guidelines on design, disinfection, and monitoring procedures of water networks of healthcare facilities should be adapted consequently and would certainly improve the offered care limiting patients' risk and avoid many unwanted financial situations for the providers.
\end{abstract}

Keywords: sanitary building; dialysis unit; water network; disinfection; Pseudomonas aeruginosa; care water

\section{Introduction}

Despite hygiene measures, microorganisms present in healthcare facilities may be responsible for nosocomial infections. Among encountered pathogenic microorganisms, Pseudomonas aeruginosa ( $P$. aeruginosa) is one of the most frequently identified. Carried by water, it can have harmful consequences for patients and remains a major concern for healthcare professionals [1]. Being highly mobile, this bacterium is widespread in the environment. It naturally lives in fresh water, sea, moist soils, and on the surface of plants. It can survive and multiply in a large variety of liquids, on any type of medium and wet material, preferably between $4{ }^{\circ} \mathrm{C}$ and $45^{\circ} \mathrm{C}$. In water distribution systems, $P$. aeruginosa develops in biofilms [2,3] which constitutes a physical barrier preventing antimicrobial agents to reach all microorganisms.

For this reason, commonly recommended doses of disinfectants are ineffective on $P$. aeruginosa $[4,5]$. Biofilms gradually liberate $P$. aeruginosa which circulates in the water distribution network and colonizes points where circulation is lower (large tubing volumes, dead or unused points, solenoid valve core, and taps). P. aeruginosa present in the distribution water systems has been shown to infect vulnerable patients [6,7]. From the medical 
point of view, P. aeruginosa is feared because is a multi-resistant microorganism with known induced morbidity [8] and directly linked mortality [9].

The water supply of healthcare facilities must be free of $P$. aeruginosa. Much effort has been dedicated to identify the origin of contamination in this context. Many reports have focused on manual or automatic faucets, distance from water mixers to the water points of use, as well as drains $[6,10,11]$ Despite these efforts, P. aeruginos a contamination is very common and surprisingly, even in newly built edifices. A report from Dijon (France) [12] showed that $4 \%$ of newly built healthcare facilities had positive samples from P. aeruginosa pointing at an improvement compared with $19 \%$ for old ones, but also showing that the problem of $P$. aeruginosa contamination of the water distribution networks still remains. The contamination of points of use in the intensive care units by $P$. aeruginosa is very frequent, sometimes more than $60 \%$ of the points [13] and Pseudomonas species have been reported to account for $88.8 \%$ of the total bacterial strains identified in dialysis units [13]. However, the presence of $P$. aeruginosa seems to be very seldom observed in the public water supply and it is generally accepted that the contamination of the distribution networks in health facilities is due to a retrograde effect coming from the patients or the users [3]. However, a German study showed that almost 3\% of the public buildings studied had P. aeruginosa in drinking water [14]. To improve the bacteriological quality of the water, many healthcare facilities use disposable sterilizing filters at the points of use (generally $0.2 \mu \mathrm{m}$ filters). Indeed, the resistance of P. aeruginosa to the disinfectants has forced closing down many healthcare facilities and brought others to use water filters at the water points of use admitting a permanent contamination of the water distribution network [15]. This approach seems effective [16] but requires appropriate maintenance and control of the structural characteristics of the filters to ensure their effectiveness [17] and be combined with more general prevention measures [18]. The purchase and maintenance cost of disposable filters being very high, it is often limited to the field of care [19]. The remaining points of use accessible to patients less frail or visitors on the periphery of the care zone (public toilet, patient bathrooms, and hand washing basin taps) are frequently not protected.

We were requested to disinfect a new dialysis building that could not be open to the public because of persistent $P$. aeruginosa contamination despite several previous decontamination attempts. We aimed at removing P. aeruginosa from the complete water distribution networks in order to subsequently guarantee a normal use of the building in its health care activities, and not being limited to the use of the protected points of the local water distribution and supply.

In addition to the water distribution systems, P. aeruginosa may contaminate very precise sites or medical material or devices. Removing P. aeruginosa is often very difficult but achievable for medical devices, as it has been reported with repeated disinfection procedures and replacement of infected parts [20] or using specific antibacterial tools applied to selected points [21]. Such techniques are unfortunately not of use to disinfect a complete water distribution system of a building. To the best of our knowledge, no successful or satisfactory eradication procedure of $P$. aeruginosa from the entire water distribution network of a health care building has been previously reported. We report the method and actions that succeeded in eradicating the infection and allowed a dialysis centre to open without restriction in the use of the water distribution system. Our general approach might help when fighting bacterial contamination of other health care buildings to eradicate the infection, without the use of filters and rendering possible the dispense of care with no restrictions.

\section{Materials and Methods}

A multi-background working group involving architects, engineers responsible for the design of the water network, builders, plumbers, maintenance technicians, water quality engineers, pharmacists, hygienists and physicians was set to decontaminate the water distribution network. The action plan was organised as follows: 


\subsection{Diagnostic and Identification of Areas at Bacterial Risk}

\subsubsection{Inspection and Evaluation of the Water Distribution System}

The water distribution system was analysed on floor layouts and engineering drawings. Risk areas of bacteriological development were pinpointed and visually identified in the building.

The risk areas were identified considering the guidelines for water distribution networks for healthcare facilities issued by the French and British governments [22,23]. Practical guidelines and advice on how to reduce bacterial contamination in vitro and in experimental settings were taken from the available literature [24,25].

\subsubsection{Bacterial Charge Quantification by ATPmetry}

Bacteriological load was quantified by ATPmetry [26]. Briefly, after a one-night period of stagnation during which no water was used, samples $(60 \mathrm{~mL})$ of water were taken directly (first jet) or after 2 min of running water (second jet) to assess whether the contamination was rather related to the point of use or to the upstream network. Adenosine triphosphate (ATP) was used as a direct quantification of the biomass to identify zones sensitive to biofilm formation.

\subsubsection{Water Sampling}

Water samples were taken and analysed by an approved laboratory (French Committee for Accreditation, COFRAC) [27]. Water sampling was performed according to the ISO 19458 [28] and FDT 90-520 standards [29]. Colony counts of aerobic bacteria at $22{ }^{\circ} \mathrm{C}$ and $36{ }^{\circ} \mathrm{C}$ were performed according to the ISO 6222 standard [30] and that of P. aeruginosa according to the standard ISO 16266 [31]. Two hundred and fifty mL were sampled and one hundred $\mathrm{mL}$ cultured to check for the presence of $P$. aeruginosa.

2.1.4. Demonstration of P. aeruginosa Contamination in Specific Segments of the Water Distribution System

Network parts (metal filters at the inlet of the network) and specialized handwash solenoid valves (Anios, Lille-Hellemmes, France) were dismantled under sterile conditions, swabbed, and cultured to detect and locate P. aeruginosa.

Some PVC pipes were cut into thin strips under aseptic conditions, fixed $2.5 \%$ glutaraldehyde in PHEM buffer, $\mathrm{pH} 7.2$ for $1 \mathrm{~h}$ at room temperature, followed by washing in PHEM buffer. Fixed samples were dehydrated using a graded ethanol series (30-100\%), followed by $10 \mathrm{~min}$ in graded ethanol-hexamethyldisilazane, and then Hexamethyldisilazane alone. Subsequently, the samples were sputter coated with an approximative $10 \mathrm{~nm}$ thick gold film and examined under a scanning electron microscope (Hitachi S4000, at CoMET, INM Montpellier France, MRI-RIO Imaging facilities, Biocampus) using a lens detector with an acceleration voltage of $10 \mathrm{KV}$ at calibrated magnifications.

\subsection{Corrective Measures}

Removal or replacements of major contaminated and contaminating sites were performed.

\subsection{Disinfection}

\subsubsection{Analysis of Previous Disinfection Procedures}

The first three disinfections were carried out by specialized companies with their own procedures. The first two disinfection procedures were examined on poorly detailed execution reports. The third procedure was observed while performed and evaluated upon completion. The fourth disinfection took into account the results of the previous disinfection audit. Hereafter, the description of the different disinfection procedures is provided.

When the building was filled with water, a chemical disinfection of the sanitary water network using a chlorinated product (Ferrocid 5280 S, Kurita Europe APW GmbH, Ludwigshafen, Germany) was carried out by a specialized company. 
The second disinfection was carried out by the same specialized company using Ferrocid 8591 (BK Giulini GmbH, Ludwigshafen, Germany), a blend of acetic acid, hydrogen peroxide, and peroxyacetic acid in water not suitable for drinking water (registered by the German CA BAuA under No.-N-16308 for a product-type (PT11) for the preservation of water or other liquids used in cooling and processing systems [32]).

The third disinfection was ordered from another specialized company. An audit was carried out and several critical points were identified: (1) the concentrated product used to disinfect was DYESE PL (Dyese, Aix en Provence, France), based on hydrogen peroxide and silver ions. Its bactericidal activity has been tested according to standards for the evaluation of the bactericidal activity of antiseptics and chemical disinfectants (EN 1040 [33], EN 1276 [34]). These standards indicate that the product is tested in laboratory tubes, but not in real conditions in distribution networks with controlled contamination levels (and presence of biofilm), so-called "dirty conditions". (2) The target level of hydrogen peroxide in the network was $1000 \mathrm{mg} / \mathrm{L}$ and the contact time was $4 \mathrm{~h}$ in line with the recommendations of the Scientific and Technical Centre for Buildings [35]. However, a pulse pump was used to introduce the disinfectant in the network without a device to regulate its flow as a function of the total water flow (no pulse water meter or flow meter). The water flow was variable depending on the number of open taps and their settings. Thus, with this method, even with a constant flow of disinfectant, the final concentration could not be even, and the minimal concentration wanted could not be guaranteed. (3) The level of hydrogen peroxide $\left(\mathrm{H}_{2} \mathrm{O}_{2}\right)$ was controlled at points of use using strip tests in which the maximum level indicator $\left(100 \mathrm{mg} / \mathrm{L} \mathrm{H}_{2} \mathrm{O}_{2}\right)$ was below the desired concentration. The samples were not diluted to adapt the test concentration ranges. Therefore, the target concentration (1000 mg/ $\mathrm{L} \mathrm{H}_{2} \mathrm{O}_{2}$ ) could not be guaranteed throughout the circuit. The results showed a clear improvement of the bacteriological quality. Of the 17 samples, only $6 \%$ contained over $100 \mathrm{CFU} / \mathrm{mL}(\max 620 \mathrm{CFU} / \mathrm{mL})$ at $22{ }^{\circ} \mathrm{C}$, and $24 \%$ contained over $10 \mathrm{CFU} / \mathrm{mL}(\mathrm{max}$ $440 \mathrm{CFU} / \mathrm{mL}$ ) at $36{ }^{\circ} \mathrm{C}$. However, P. aeruginosa was still present in 4 samples. Therefore, an additional decontamination procedure was needed.

\subsubsection{Proposed Disinfection Procedure}

The fourth disinfection took into account the results of the previous disinfection audit. It used a proportional pump (DOSATRON ${ }^{\circledR}$ INTERNATIONAL S.A. Tresses, France) and a disinfectant, Dialox ${ }^{\circledR}$ (S\&M FRANCE-BIOXAL, Chalon sur Saône, France), tested according to application standards in "dirty conditions" (NF 13727). Dialox ${ }^{\circledR}$ is a disinfectant based on hydrogen peroxide and peracetic acid which is adapted for medical and water treatment devices. Water and disinfectant flows were adjusted to obtain $1000 \mathrm{mg} / \mathrm{L}$ of $\mathrm{H}_{2} \mathrm{O}_{2}$ directly after the main water inlet and uniformly throughout the network using a proportional pump. The presence and concentration of the disinfectant was checked in samples diluted $1 / 20$ using a strip with a concentration range $0-100 \mathrm{mg} / \mathrm{L}$ of $\mathrm{H}_{2} \mathrm{O}_{2}$. The network was filled up and checked to contain $1000 \mathrm{mg} / \mathrm{L}$ of $\mathrm{H}_{2} \mathrm{O}_{2}$ at all sampling and user points. The contact time was more than $8 \mathrm{~h}$.

Water samples for analysis were taken at least $72 \mathrm{~h}$ after decontamination and rinsing, and repeated more than one week apart. These samples were taken in the first jet after a minimum period of stagnation of one night. Then, bacteriologic analyses at $22{ }^{\circ} \mathrm{C}$ and $36{ }^{\circ} \mathrm{C}$ were conducted in compliance with regulations.

\subsection{Maintenance Measures}

In order to avoid bacterial proliferation after disinfection, regular flushes (two min daily, weekly, or monthly according to risk level) of all points of use were introduced.

Periodic sampling for laboratory analysis of selected points of use was performed to monitor the bacterial charge and water stability. A range of 10 to 20 water samples were taken quarterly. 


\section{Results}

\subsection{Diagnostic and Identification of Areas at Bacterial Risk}

\subsubsection{Inspection and Evaluation of the Water Distribution System}

The building was connected to the public water distribution network by an external pipe approximately $50 \mathrm{~m}$ long. This pipe fed a garden water tap, as well as two separated pipes in the basement level. One pipe going to the water treatment unit for dialysis and three outdoor taps, and the other one going to the sanitary water network (Figure 1).

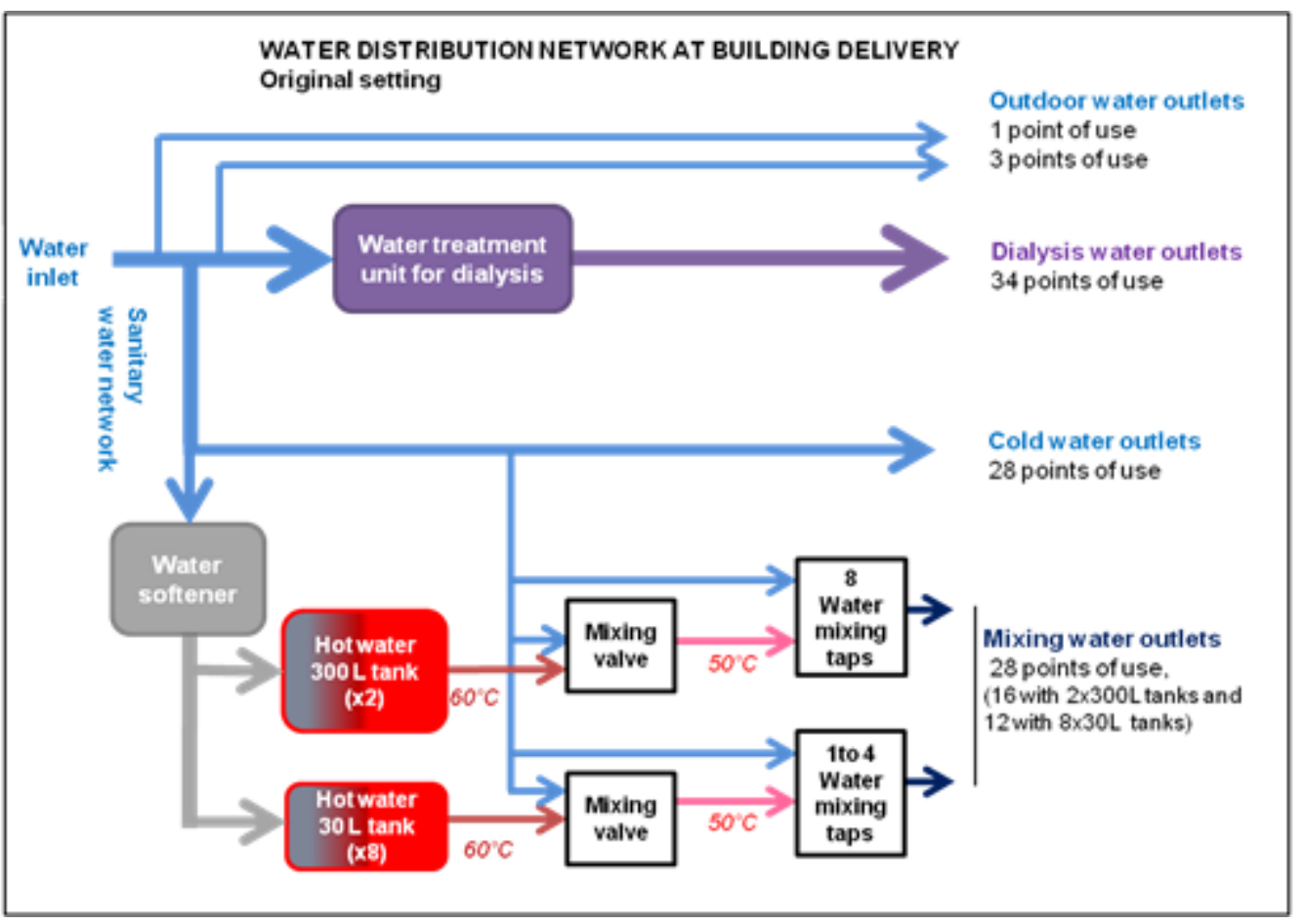

Figure 1. Schematic water distribution network. Original setting when the building was delivered. A garden water tap was connected to the main pipe. Three taps for outdoor use were connected to the pipe specifically dedicated to the treatment of dialysis water. A $50 \mathrm{~L}$ ion-exchange softener supplied 10 hot water tanks: two $300 \mathrm{~L}$ and eight $30 \mathrm{~L}$ capacity for the most distant points of use in the building. These hot water tanks had a mixing valve downstream to limit the temperature of hot water outputs to $50{ }^{\circ} \mathrm{C}$ to avoid the risk of burns for users. The record of the temperature at the entrance of the building at the time of the procedures was $15-16^{\circ} \mathrm{C}$, and inside the building it was $17-18{ }^{\circ} \mathrm{C}$.

The water treatment unit for dialysis includes filtration, softening, and de-chlorination steps before a double osmosis and supplies 34 points of use (dialysis treatment points). The sanitary water network supplied 56 points of use: 28 cold water outlets ( 5 mechanical taps and 23 contactless taps) and 28 mixing taps (cold and hot water). Hot water $\left(60{ }^{\circ} \mathrm{C}\right.$ ) was obtained after softening with a $50 \mathrm{~L}$ ion-exchange softener from two $300 \mathrm{~L}$ hot water tanks each supplying eight water mixers. The first tank supplies the area used by patients and visitors on levels 0 and 1 . The second one supplies the area reserved to the staff on level 2. Eight $30 \mathrm{~L}$ hot water tanks individually supplied one to four water mixing taps each. Cooling water from $60{ }^{\circ} \mathrm{C}$ to $50{ }^{\circ} \mathrm{C}$ maximum was obtained by mixing valves placed between the hot water tanks and the water mixing taps; the distance between the water mixing taps and the mixing valves was between $3 \mathrm{~m}$ and $10 \mathrm{~m}$ long. For the control of different types of water (cold, softened, hot, mixed, and dialysis water), 12 sampling sites were installed on the different pipes.

Inspection and evaluation of the water distribution system showed poor separation of water distribution networks (external taps connected to the pipe dedicated to dialysis water (Figure 1)), dead legs (Figure 2), unfavourable equipment (automatic taps), and significant 
lengths of piping after the large hot water tanks resulting in possible water temperature drops below $50{ }^{\circ} \mathrm{C}$ (Figure 1).

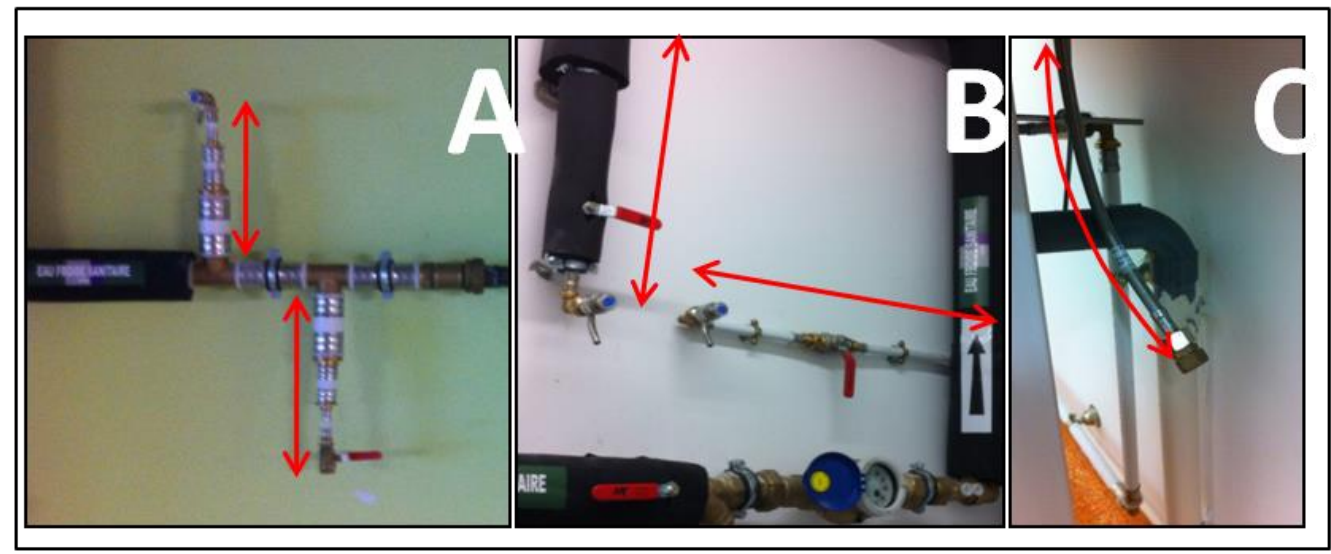

Figure 2. Dead legs in the network: (A,B) display examples of dead legs related to the sampling sites with long arms outside from the main stream (arrows). (C) illustrates the case of a tap envisaged for providing hot and cold water of which only cold water was used, and the remaining unused tubing was capped, creating a dead leg.

\subsubsection{ATPmetry Results}

Mapping of the water distribution networks by ATPmetry made it possible to draw up a microbiological intensity map of the installation to identify the zones and the points of use likely to create the conditions of biofilm formation. The majority of points of use and sampling taps on the different networks were checked ( $n=40$, Figure 3$)$. It can be observed that a large majority of samples $(71 \%)$ were over the recommended threshold of $2 \log$ equivalent bact $/ \mathrm{mL}$, and a considerable proportion $(38 \%)$ had very high content ( $\geq 3 \log$ equivalent bact $/ \mathrm{mL}$ ).

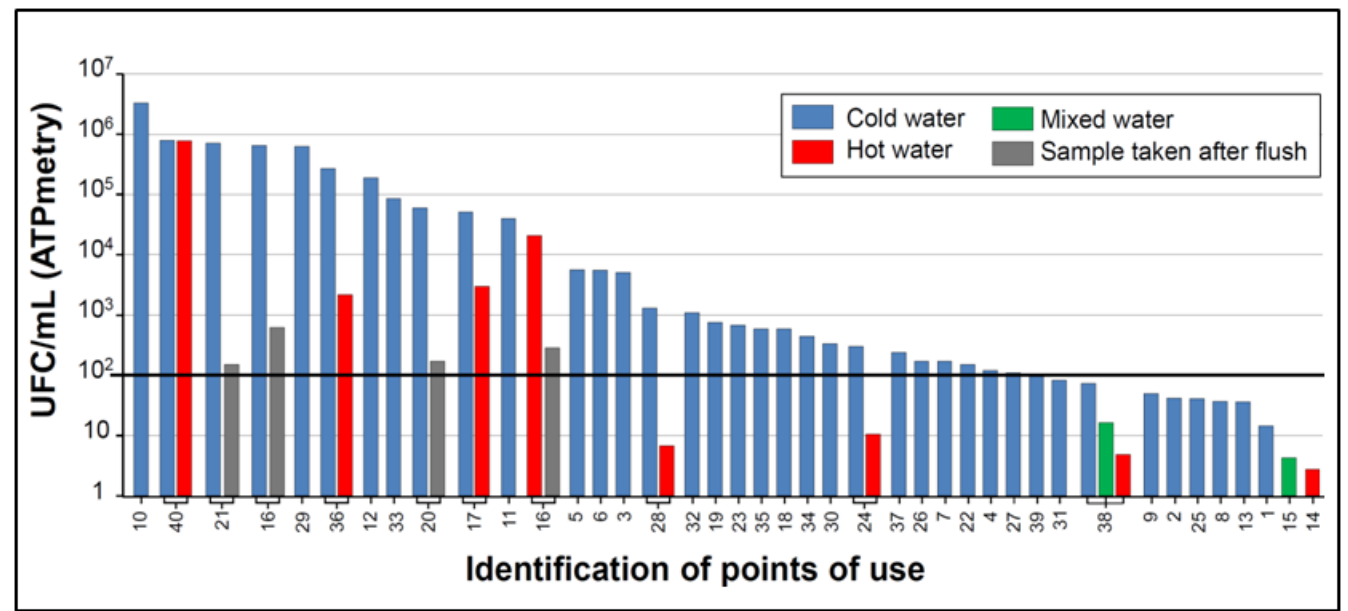

Figure 3. Mapping of points of use by ATPmetry. A total of $71 \%$ of the points are above the quality objectives $\left(10^{2}\right.$ equivalent bacteria, solid line). All samples were made in the first jet only except for the points of use 16 (hot and cold water), 20, and 21 for which the second jet was also analysed. At this stage, 20 out of 26 sites identified at risk (77\%) were positive for P. aeruginosa.

To better identify the sites at risk of bacterial contamination, a comparison between bacterial content found in the first and second jets was carried out at different relevant points of use. Since the first jet is related to the local bacterial status and the second jet is rather related to the bacterial status of the water of the system, a high first/second jet bacterial number reduction (from $5.2 \pm 0.4$ to $2.4 \pm 0.1 \log$ equiv bact/mL) is strongly 
suggestive of local bacterial production. Thereby, significant contamination levels were observed and located on (i) automatic faucets, (ii) the softener, (iii) the network portion from the softener to the hot water tanks, (iv) the observed dead legs, and (v) showers equipped with thermostatic faucets.

\subsubsection{Water Sampling}

Water samples from the sampling taps located on the pipes at the beginning of the sanitary water network and of the water treatment unit for dialysis were found negative for $P$. aeruginosa.

On the other hand, most of the samples in the sites identified at risk (20 out of 26, 77\%) were positive for $P$. aeruginosa: dead legs and automatic cold-water taps, after the sanitary water softener (sample sites and mixed water taps).

3.1.4. Demonstration of P. aeruginosa Contamination in Specific Segments of the Water Distribution System

- $\quad$ Filters of the main pipes

The filters were opened in sterile conditions and parts were swabbed and cultured. The presence of $P$. aeruginosa was demonstrated in the filters at the entry of the water distribution network, whilst there was no P. aeruginosa in the sample taken before the filter to test the conformity of the water supply from the city provider. The presence of pebbles was observed in these filters. It is noteworthy that all samples were obtained in the old dialysis building at the same location, and importantly, shared the same water source that had been negative for $P$. aeruginosa during the 10-year exploitation period. Likewise, the filters in the old building were never found to contain any visible gravel. The origin of the contamination of the new building is likely to be related to the connection to the municipal water distribution system. The large number of bacteria along the network also shows that the first disinfection performed immediately after connecting the water network failed, as did the regular purging of water at points of use performed before opening the building to patients.

- $\quad$ Automated hand washing taps.

We disassembled the solenoid valves from our six automated hand washing points from the care zone. We cultured samples from the internal parts of these solenoid valves. The presence of $P$. aeruginosa on the solenoid valve nucleus was confirmed in those already found positive in previous analyses. All solenoid valves were changed and the internal circuit was disinfected. The analyses that followed were no longer positive for the presence of $P$. aeruginosa.

- Water treatment unit for dialysis.

$P$. aeruginosa was also identified in two sampling sites located after the water softener of the treatment unit for dialysis and after the activated carbon column (before reverse osmosis). Investigations showed that the softener as well as the activated charcoal were free of $P$. aeruginosa whilst the sampling sites were infected. The tubing of these sampling sites was analysed (Figure 4A). The piping was cut in sterile conditions and prepared for electron microscopy analysis. It showed the presence of bacteria with size and shape similar to that of P. aeruginosa (Figure 4B). The setting of the sampling sites was modified to reduce the dead legs and avoid stagnation (Figure 4C). Finally, a new disinfection of the water treatment unit was performed, which repeatedly demonstrated the absence of $P$. aeruginosa. 


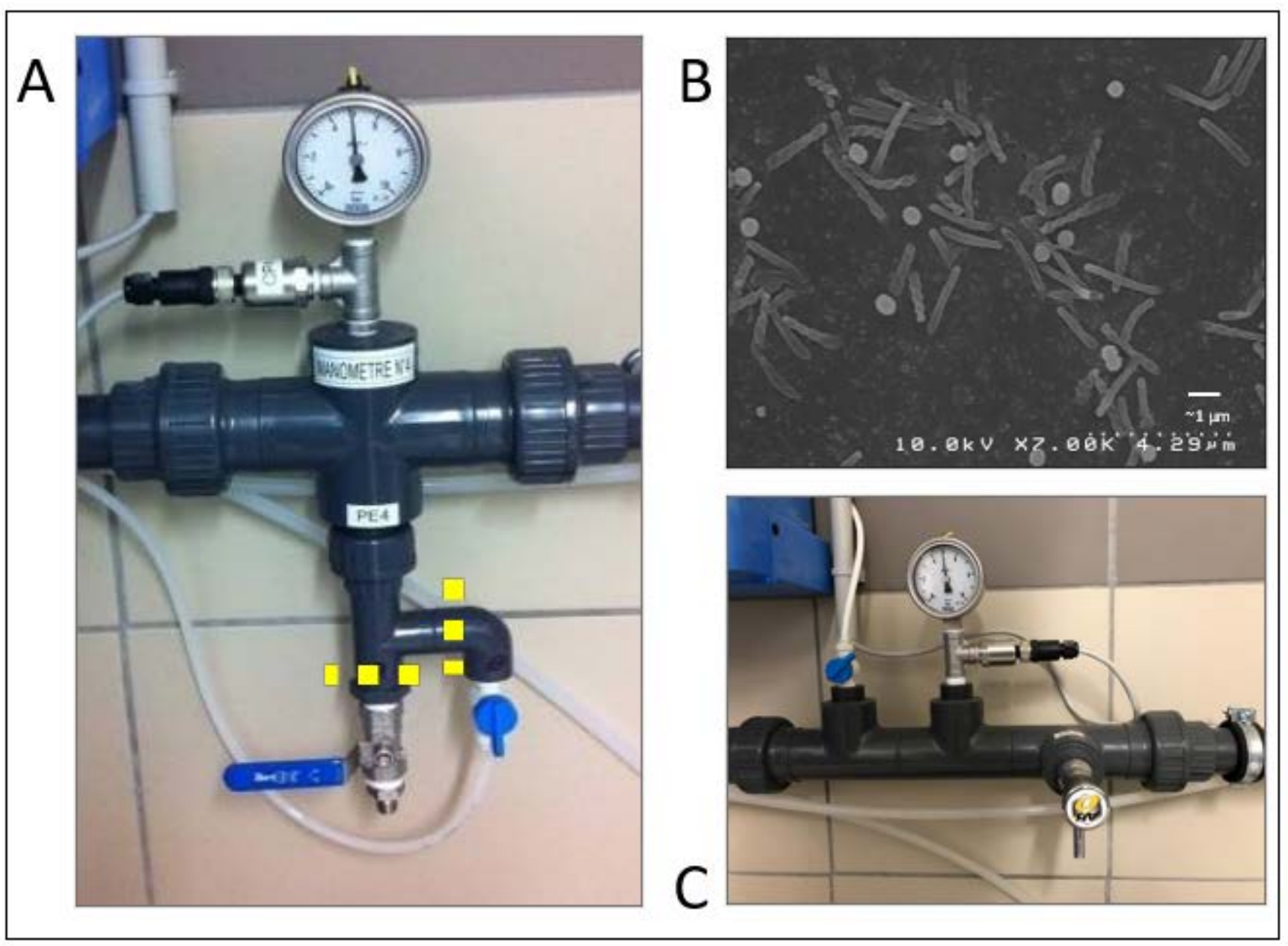

Figure 4. Water treatment unit for dialysis. (A) Portion of the network including the connection between the water softener and activated carbon filter, with manometer and pressure sensor on the upper part and the sampling line for automatic calcium control and the manual sampling point below the main water flow (favouring stagnation and increasing dead space). Two sections (yellow lines) were made and prepared for microscopic observation. (B) Pseudomonas were characterised by electron microscopy in the slices of the tubes for automatic calcium control and the manual sampling. (C) The portion shown in A was modified to remove stagnation points and reduce dead legs.

\subsection{Corrective Measures in the Water Distribution Network}

Several corrective and preventive measures were carried out to secure the network. The main ones are described in Table 1 and plotted in the engineering drawings of the supplementary figures (Supplementary Materials Figures S1-S4). The resulting network is schematized in Figure 5.

\subsection{Disinfection}

Eight days apart, the fourth disinfection specific to P. aeruginosa cultures performed returned negative. A new control, eight days later was also negative and the healthcare facility could be opened to the public.

Three months later, three points of use were positive to P. aeruginosa. A supplementary disinfection procedure was carried out which was successful. Subsequent controls were negative for P. aeruginosa. 
Table 1. Facility features increasing the risk of contamination and proposed corrections.

\begin{tabular}{|c|c|c|}
\hline Feature Type & Features Enhancing Contamination & Correction \\
\hline Missing equipment & $\begin{array}{l}\text { On the main water supply, there was no } \\
\text { possibility of carrying out controlled } \\
\text { chemical decontamination. }\end{array}$ & $\begin{array}{l}\text { Installation of connectors to install a } \\
\text { volume-controlled mixing pump for chemical } \\
\text { disinfection. }\end{array}$ \\
\hline Network & $\begin{array}{l}\text { Outdoor taps were connected to a pipe } \\
\text { dedicated to the treatment of water for } \\
\text { dialysis. }\end{array}$ & Separation of the two networks \\
\hline Network & Dead legs & Shorten or remove the dead legs \\
\hline Network & $\begin{array}{l}\text { Presence of thermostatic valves mixing } \\
\text { hot and cold water, distant from points of } \\
\text { use (range: } 3-10 \mathrm{~m} \text { ) }\end{array}$ & $\begin{array}{l}\text { Removal of hot and cold water mixing valves } \\
\text { located over } 3 \mathrm{~m} \text { from point of use. Mechanical } \\
\text { adjustment of maximum allowable temperature } \\
\left(50^{\circ} \mathrm{C}\right) \text { on user taps }\end{array}$ \\
\hline Unfavourable equipment & Large water softener & Removal of the water softener \\
\hline Unfavourable equipment & Thermostatic faucets & Change for simple mixing faucets \\
\hline Unfavourable equipment & $\begin{array}{l}\text { Automatic faucets without automatic } \\
\text { periodic rinsing }\end{array}$ & Change for manual faucets \\
\hline Unfavourable equipment & Faucet aerators & $\begin{array}{l}\text { Replacement by flow straightener and specific } \\
\text { disinfection }\end{array}$ \\
\hline Unfavourable equipment & Solenoid valves of specialized faucets & Replacement and specific disinfection \\
\hline
\end{tabular}

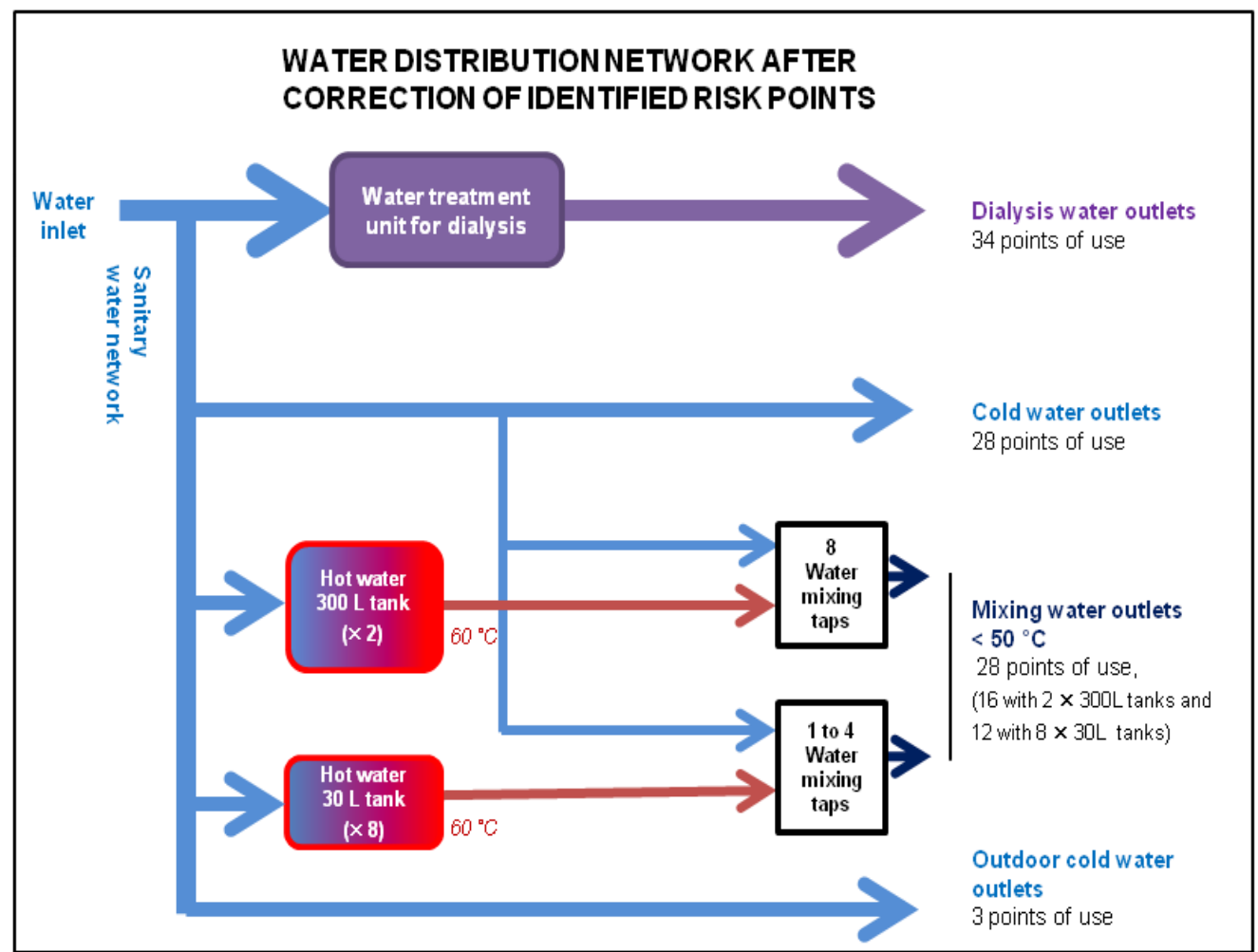

Figure 5. Schematic water distribution network after correction of the identified risk points. The garden water tap was removed. The water line feeding the 3 external taps was separated from the water line for dialysis treatment and the softener was removed. The water mixing valves of the large hot water tanks were removed because they were located several $\mathrm{m}$ ( 3 to $10 \mathrm{~m}$ ) from points of use. This arrangement resulted in a long portion of tube with intermediate temperatures promoting bacterial development. The maximum hot water temperature is presently set at the point of use. 


\subsection{Maintenance and Controls}

Periodic network rinsing and monitoring of the presence of P. aeruginosa was pursued during use. Over the following 3 years, 219 out of 223 (98\%) analyses were negative $(<1 \mathrm{CFU} / 100 \mathrm{~mL})$. Four positive results were linked to three taps not used for care which were satisfactorily treated locally. No recurrence of P. aeruginosa infection has been observed in the water treatment unit for dialysis.

\section{Discussion}

Previous reports on P. aeruginosa contamination mainly focus on retrograde contamination from the patients or users to the water network. There is scant information on the origin of a water contamination, the location where biofilms develop, or the methods to remove those [36]. A first successful attempt to decrease bacterial contamination of a multiple sclerosis centre has been reported [37]. In that study, the authors applied an electrochemical disinfection in the hot water network before the heater with a recirculation system. It represents an interesting approach that deserves being tested in cold water used for care. To the best of our knowledge, our report is the first case illustrating a contamination of a new health care building, describing the measures applied to eliminate it, and showing the unsatisfactory treatments as well as the finally successful approach. In addition, our experience underlines the importance of preventive measures, not only in the design of internal water distribution, but also and above all in the execution process of the construction phases, and in particular at the time of the arrival of water in the building, the disinfection of the networks, and the expectation of the opening to the public.

Our approach, through a careful visual inspection of all water systems guided by the recommendations of the ministries of health and scientific literature, and by an ATPmetry mapping coupled with bacteriological results, allowed us to identify areas and points of use at risk of biofilm development. Design errors were identified and corrective measures were applied. We also observed that the sizing of the network was not adapted to the facility. The estimated water consumption was significantly higher than that actually used and the planned number of points of use exceeded that required for healthcare activity. The first favoured a slow speed of water circulation in the pipes and the second allowed the appearance of dead and unused legs, favouring bacterial growth and biofilm formation [38]. The capacity of the water softener protecting hot water piping from limestone has been estimated to be one hundred times greater than that actually used. As a consequence, the water flow in the softener was very low, again, allowing bacterial proliferation to occur. In addition, water at the main inlet was only moderately loaded with calcium, rendering questionable the necessity of the softener. For hand washing, the choice to generalize automatic non-touch censor taps was not suitable because these taps, especially with core solenoid valves, are known to be a trap for germs [39].

In the present experience, although the quality of the water supplied by the municipality is acceptable, the complete water network of the facility was shown to be contaminated shortly after connecting the main water inlet. It appears that the moment of connecting and filling up the distribution system is crucial, although there is no established protocol for its implementation. During the 3 months spent between the end of the construction works of the building and its equipment for healthcare activities, no particular measures, except periodic flushing, were scheduled to check and maintain the quality of water in the distribution networks. Nevertheless, air tightness checking of the water distribution networks and maintenance with super-chlorinated water or other recommended solutions are advised by good practice recommendations [40]. None of these actions were undertaken in our case. Indeed, several important problems were observed in the curative disinfection practices used. The disinfectant products used had not been validated in real conditions and the implementation was poorly controlled. Instead, disinfectants that are efficient for biofilm destruction, compatible with network materials, and without health risk should have been favoured. Thermal disinfection [41], if properly performed, is effective but not always technically feasible on the entire water network of a building. 
From a more general point of view, the design of sanitary networks must comply with numerous documents, national regulations, technical design documents, or technical guides. All parts of the network must also comply with national or international standards. These texts include different requirements, the first of which being that the quality of the water does not deteriorate in the network and remains in conformity with the standards of quality at any point of use. Amongst additional more technical requirements are that the water flow at all points should be in conformity with reference values without pressure drop; there should be no return of polluted water to the drinking water system; there should be protection against calcareous deposits; hot water temperatures should not reach a threshold considered to increase the risk of injury and burning at the point of use. In addition, the design of a water distribution network is limited by budget constraints being frequently at odds with the primary goal of good water quality for health facilities. Engineers and workers responsible for the implementation of the water networks are often better trained on the technical aspects of proper functioning than on the risks of water quality degradation described in the scientific literature and in the health guidelines. Water networks of new buildings can therefore be affected by microorganisms which can be sometimes pathogenic. Therefore, the creation of a multidisciplinary working group to design a water network, monitor the progress of the construction, and control the intermediate phase between the water connection and opening is of outmost importance.

\section{Conclusions}

In conclusion, $P$. aeruginosa contamination of newly constructed health facilities is very difficult to resolve. There is no effective method applicable to all buildings because network configurations, materials, water quality, or uses are different. However, with a good methodology it may be possible to decrease the contamination and possibly eradicate it. Proper diagnostic methods, corrective measures, and disinfection procedures carefully chosen and followed in their implementation should be used.

Misunderstanding or non-compliance with regulatory texts or guidelines for the design, operation, and maintenance of the internal water distribution networks of new health care facilities can lead to poor water quality, sometimes incompatible with the function the edifice has been built for. The health risk linked to bacterial infections carried by the water distribution network in health care facilities may be unacceptably high [9] and the financial consequences of poor water quality important. Correcting design-based problems and mishandlings of the setup phase can represent a high cost, especially as it postpones the start of healthcare activity. International guidelines for the design, setup phase, and maintenance of water distribution networks of healthcare facilities should be developed in collaboration with builders, health authorities, and water quality specialists. Their implementation in new buildings should be specifically supervised by trained specialists at all stages, from design to start of activity.

Supplementary Materials: The following supporting information can be downloaded at: https: / /www.mdpi.com/article/10.3390/hygiene2010001/s1, Figure S1: Network corrections on basement ( -1 level); Figure S2: Network corrections on the ground floor; Figure S3: Network corrections on the first floor; Figure S4: Network modifications on the second floor.

Author Contributions: Conceptualization, A.F. and À.A.; methodology, A.F., J.R., J.L., C.B., N.G., F.D., C.C. and À.A.; resources, F.V., I.S., M.-F.S. and À.A.; writing-original draft preparation A.F. and À.A.; writing-review and editing, J.L., N.G., F.D., F.V. and I.S. All authors have read and agreed to the published version of the manuscript.

Funding: This research received no external funding.

Institutional Review Board Statement: No involvement of humans. Not applicable.

Data Availability Statement: Data may be available upon request at the dialysis clinic. Available online: http:/ / www.ndsg.fr / (accessed on 17 December 2021). 
Acknowledgments: The active participation of Didier Landemaine is acknowledged and the support of Aurélie Laden, Sylvie Febbraro, Gilles Goubert, and the staff of NDSG appreciated. Cèlia Argilés helped in preparing the plans for this report. Estelle Jumas-Bilak is recognised for participating with helpful discussions and advice and N. Fabre from BIOCONTROL for performing the ATPmetry.

Conflicts of Interest: The authors declare no conflict of interest.

\section{References}

1. Venier, A.-G.; Leroyer, C.; Slekovec, C.; Talon, D.; Bertrand, X.; Parer, S.; Alfandari, S.; Guerin, J.-M.; Megarbane, B.; Lawrence, C.; et al. Risk Factors for Pseudomonas aeruginosa Acquisition in Intensive Care Units: A Prospective Multicentre Study. J. Hosp. Infect. 2014, 88, 103-108. [CrossRef]

2. Watnick, P.; Kolter, R. Biofilm, City of Microbes. J. Bacteriol. 2000, 182, 2675-2679. [CrossRef] [PubMed]

3. Wingender, J.; Flemming, H.-C. Biofilms in Drinking Water and Their Role as Reservoir for Pathogens. Int. J. Hyg. Environ. Health 2011, 214, 417-423. [CrossRef] [PubMed]

4. Lenz, J.; Linke, S.; Gemein, S.; Exner, M.; Gebel, J. Verification of the Efficiency of Chemical Disinfection and Sanitation Measures in In-Building Distribution Systems. Int. J. Hyg. Environ. Health 2010, 213, 198-203. [CrossRef] [PubMed]

5. Schwering, M.; Song, J.; Louie, M.; Turner, R.J.; Ceri, H. Multi-Species Biofilms Defined from Drinking Water Microorganisms Provide Increased Protection against Chlorine Disinfection. Biofouling 2013, 29, 917-928. [CrossRef]

6. $\quad$ Loveday, H.P.; Wilson, J.A.; Kerr, K.; Pitchers, R.; Walker, J.T.; Browne, J. Association between Healthcare Water Systems and Pseudomonas aeruginosa Infections: A Rapid Systematic Review. J. Hosp. Infect. 2014, 86, 7-15. [CrossRef] [PubMed]

7. Trautmann, M.; Bauer, C.; Schumann, C.; Hahn, P.; Höher, M.; Haller, M.; Lepper, P.M. Common RAPD Pattern of Pseudomonas aeruginosa from Patients and Tap Water in a Medical Intensive Care Unit. Int. J. Hyg. Environ. Health 2006, 209, 325-331. [CrossRef] [PubMed]

8. Kerr, K.G.; Snelling, A.M. Pseudomonas aeruginosa: A Formidable and Ever-Present Adversary. J. Hosp. Infect. 2017, 73, 338-344. [CrossRef]

9. Regulation and Quality Improvement Authority-RQIA. Inspection Reports I Regulation and Quality Improvement Authority Standards Reports. Available online: https:/ / www.rqia.org.uk/reviews/review-reports/2012-2015/rqia-pseudomonas-review / rqia-independent-review-of-pseudomonas-final-repor/ (accessed on 17 December 2021).

10. Walker, J.T.; Jhutty, A.; Parks, S.; Willis, C.; Copley, V.; Turton, J.F.; Hoffman, P.N.; Bennett, A.M. Investigation of HealthcareAcquired Infections Associated with Pseudomonas aeruginosa Biofilms in Taps in Neonatal Units in Northern Ireland. J. Hosp. Infect. 2014, 86, 16-23. [CrossRef]

11. Bédard, E.; Prévost, M.; Déziel, E. Pseudomonas aeruginosa in Premise Plumbing of Large Buildings. MicrobiologyOpen 2016, 5, 937-956. [CrossRef]

12. Lefebvre, A.; Quantin, C.; Vanhems, P.; Lucet, J.-C.; Bertrand, X.; Astruc, K.; Chavanet, P.; Aho-Glélé, L.S. Impact of New Water Systems on Healthcare-Associated Colonization or Infection with Pseudomonas aeruginosa. 2016. Available online: https: //www.ncbi.nlm.nih.gov/pmc/articles/PMC4886352/ (accessed on 15 December 2021).

13. Lucena, R.; Boccato, C.; Vienken, J.; Evans, D. Water and Dialysis Fluids: A Quality Management Guide; Patbst Science Publishers: Lengerich, Germany, 2015.

14. Völker, S.; Schreiber, C.; Kistemann, T. Drinking Water Quality in Household Supply Infrastructure-A Survey of the Current Situation in Germany. Int. J. Hyg. Environ. Health 2010, 213, 204-209. [CrossRef]

15. Ortolano, G.A.; McAlister, M.B.; Angelbeck, J.A.; Schaffer, J.; Russell, R.L.; Maynard, E.; Wenz, B. Hospital Water Point-of-Use Filtration: A Complementary Strategy to Reduce the Risk of Nosocomial Infection. Am. J. Infect. Control 2005, 33, S1-S19. [CrossRef]

16. Trautmann, M.; Halder, S.; Hoegel, J.; Royer, H.; Haller, M. Point-of-Use Water Filtration Reduces Endemic Pseudomonas aeruginosa Infections on a Surgical Intensive Care Unit. Am. J. Infect. Control 2008, 36, 421-429. [CrossRef]

17. Totaro, M.; Valentini, P.; Casini, B.; Miccoli, M.; Costa, A.L.; Baggiani, A. Experimental Comparison of Point-of-Use Filters for Drinking Water Ultrafiltration. J. Hosp. Infect. 2017, 96, 172-176. [CrossRef]

18. Baranovsky, S.; Jumas-Bilak, E.; Lotthé, A.; Marchandin, H.; Parer, S.; Hicheri, Y.; Romano-Bertrand, S. Tracking the Spread Routes of Opportunistic Premise Plumbing Pathogens in a Haematology Unit with Water Points-of-Use Protected by Antimicrobial Filters. J. Hosp. Infect. 2018, 98, 53-59. [CrossRef]

19. Garvey, M.I.; Bradley, C.W.; Wilkinson, M.A.C.; Bradley, C.; Holden, E. Engineering Waterborne Pseudomonas aeruginosa out of a Critical Care Unit. Int. J. Hyg. Environ. Health 2017, 220, 1014-1019. [CrossRef]

20. Qiu, L.; Zhou, Z.; Liu, Q.; Ni, Y.; Zhao, F.; Cheng, H. Investigating the Failure of Repeated Standard Cleaning and Disinfection of a Pseudomonas aeruginosa-Infected Pancreatic and Biliary Endoscope. Am. J. Infect. Control 2015, 43, e43-e46. [CrossRef]

21. Khan, S.I.; Blumrosen, G.; Vecchio, D.; Golberg, A.; McCormack, M.C.; Yarmush, M.L.; Hamblin, M.R.; Austen, W.G. Eradication of Multidrug-Resistant Pseudomonas Biofilm with Pulsed Electric Fields: Eradication of Multidrug-Resistant Pseudomonas. Biotechnol. Bioeng. 2016, 113, 643-650. [CrossRef]

22. Ministère Des Solidarités et de La Santé. Qualité de l'eau Dans Les Établissements de Santé. Available online: https://solidarites-sante. gouv.fr/sante-et-environnement/eaux/article/qualite-de-l-eau-dans-les-etablissements-de-sante (accessed on 21 October 2019). 
23. Safe Water in Healthcare Premises (HTM 04-01). Available online: https:/ /www.gov.uk/government/publications/hot-andcold-water-supply-storage-and-distribution-systems-for-healthcare-premises (accessed on 5 October 2020).

24. Walker, J.; Moore, G. Pseudomonas aeruginosa in Hospital Water Systems: Biofilms, Guidelines, and Practicalities. J. Hosp. Infect. 2015, 89, 324-327. [CrossRef]

25. Suchomel, M.; Diab-Elschahawi, M.; Kundi, M.; Assadian, O. Influence of Pre- and Post-Usage Flushing Frequencies on Bacterial Water Quality of Non-Touch Water Fittings. BMC Infect. Dis. 2013, 13, 402. [CrossRef]

26. van der Kooij, D.; Vrouwenvelder, J.S.; Veenendaal, H.R. Elucidation and Control of Biofilm Formation Processes in Water Treatment and Distribution Using the Unified Biofilm Approach. Water Sci. Technol. J. Int. Assoc. Water Pollut. Res. 2003, 47, 83-90. [CrossRef]

27. Accueil I COFRAC-Comité Français D'accréditation. Available online: https:/ / www.cofrac.fr/ (accessed on 18 February 2020).

28. ISO 19458:2006(En), Water Quality-Sampling for Microbiological Analysis. Available online: https://www.iso.org/obp/ui/\#iso: std:iso:19458:ed-1:v1:en (accessed on 17 February 2020).

29. FD T90-520-Octobre 2005. Available online: https://www.boutique.afnor.org/norme/fd-t90-520/qualite-de-1-eau-guidetechnique-de-prelevement-pour-le-suivi-sanitaire-des-eaux-an-application-du-code-de-la-sante-publique/article/678996 / fa140129?gclid=CjwKCAjwiOv7BRBREiwAXHbv3HDU-AYhe2SFXGYOo5RBZnzPYV2MJBbjoVzOPZCHqnrwb43XN3 ZoQBoCUUoQAvD_BwE (accessed on 5 October 2020).

30. ISO 6222:1999(En), Water Quality-Enumeration of Culturable Micro-Organisms-Colony Count by Inoculation in a Nutrient Agar Culture Medium. Available online: https://www.iso.org/obp/ui/\#iso:std:iso:6222:ed-2:v1:en:sec:foreword (accessed on 18 February 2020).

31. ISO 16266:2006(En), Water Quality—Detection and Enumeration of Pseudomonas aeruginosa-Method by Membrane Filtration. Available online: https://www.iso.org/obp/ui/\#iso:std:iso:16266:ed-1:v1:en (accessed on 18 February 2020).

32. Product-Types-ECHA. Available online: https://echa.europa.eu/regulations/biocidal-products-regulation/product-types (accessed on 18 February 2020).

33. NF EN 1040-Avril 2006. Available online: https://www.boutique.afnor.org/norme/nf-en-1040/antiseptiques-et-desinfectantschimiques-essai-quantitatif-de-suspension-pour-l-evaluation-de-l-activite-bactericide-de-base-des/article/727990/fa139438 (accessed on 18 February 2020).

34. NF EN 1276-Août 2019. Available online: https://www.boutique.afnor.org/norme/nf-en-1276/antiseptiques-et-desinfectantschimiques-essai-quantitatif-de-suspension-pour-l-evaluation-de-l-activite-bactericide-des-antisep/article/915853/fa189955? lang=13\&gclid=Cj0KCQiAs67yBRC7ARIsAF49CdVfFyKUPwmq8N8jhk-jhItTo4v2ob-7DgNSijRZaWdhthLJDIANNKwaAgP9 EALw_wcB (accessed on 18 February 2020).

35. Réseaux d'eau Destinée à la Consommation Humaine à l'intérieur des Bâtiments: Guide Technique de Maintenance. Désinfection Chimique d'un Réseau EFS et/ou ECS, Centre Scientifique et Technique du Bâtiment. 2005, p. 83. Available online: https: / / boutique.cstb.fr/reseaux-d-eau-et-assainissement/268-reseaux-deau-destinee-a-la-consommation-humainea-linterieur-des-batiments-partie-2-9782868913258.html (accessed on 5 October 2020).

36. Falkinham, J.; Pruden, A.; Edwards, M. Opportunistic Premise Plumbing Pathogens: Increasingly Important Pathogens in Drinking Water. Pathogens 2015, 4, 373-386. [CrossRef] [PubMed]

37. Cossali, G.; Routledge, E.J.; Ratcliffe, M.S.; Blakes, H.; Fielder, J.E.; Karayiannis, T.G. Inactivation of E. Coli, Legionella, and Pseudomonas in Tap Water Using Electrochemical Disinfection. J. Environ. Eng. 2016, 142, 04016063. [CrossRef]

38. Bédard, E.; Laferrière, C.; Déziel, E.; Prévost, M. Impact of Stagnation and Sampling Volume on Water Microbial Quality Monitoring in Large Buildings. PLoS ONE 2018, 13, e0199429. [CrossRef] [PubMed]

39. Moore, G.; Stevenson, D.; Thompson, K.-A.; Parks, S.; Ngabo, D.; Bennett, A.M.; Walker, J.T. Biofilm Formation in an Experimental Water Distribution System: The Contamination of Non-Touch Sensor Taps and the Implication for Healthcare. Biofouling 2015, 31, 677-687. [CrossRef]

40. Centre Scientifique et Technique du Bâtiment; Agence Régionale de la Santé Pays de Loire. Document d'aide à La Conception Des Installations d'eau Sanitaire à l'intérieur Des Bâtiments. Available online: https:/ /www.normandie.ars.sante.fr/system/ files/2018-01/conception_reseauxECS.pdf (accessed on 21 October 2019).

41. van der Mee-Marquet, N.; Bloc, D.; Briand, L.; Besnier, J.-M.; Quentin, R. Non-Touch Fittings in Hospitals: A Procedure to Eradicate Pseudomonas aeruginosa Contamination. J. Hosp. Infect. 2005, 60, 235-239. [CrossRef] 